\title{
A Giant Mesenchymal Pericardial Cyst: A Rare cause of Hoarseness of Voice, Case Report and Review of Literature
}

\author{
Ahsan Cheema, Hadi Mutairi, Deena Boqari, Manal Al Naimi and Ikram Chaudhry* \\ Department of Thoracic surgery, King Fahad Specialist Hospital Dammam, Saudi Arabia
}

Submission: May 07, 2018; Published: May 17, 2018

*Corresponding author: Ikram ul haq Chaudhry, Department of Thoracic Surgery, King Fahad Specialist Hospital Dammam, Saudi Arabia, Email: drihc007@gmail.com

\begin{abstract}
We report a case of 32 years women who presented to us with history of shortness of breath and hoarseness of voice for the last three weeks. Chest x-ray showed wide mediastinum. Computed tomographic scan of chest (CT) showed large anterior mediastinal cystic mass. Fiber optic bronchoscopy showed impaired movement of left vocal cord. A giant cyst was excised through median sternotomy and histology report revealed, "Mesenchymal pericardial cyst".
\end{abstract}

Keywords: Mediastinal cyst; pericardial; Hoarseness of voice; Surgery.

\section{Introduction}

Pericardial cysts are exceedingly rare benign lesions which constitutes $35 \%$ of the mediastinal cystic lesions and $7 \%$ of overall mediastinal masses. The reported incidence of pericardial cysts is $1: 1,00,000$, commonly seen in the third or fourth decade of life equally affecting both genders [1,2]. In 1958 Le Roux reported only three cases of pericardial cysts after reviewing 3000 chest $\mathrm{x}$-rays. They are described in medical literature under various names pleuropericadial cyst, pleural cysts, spring water cysts, pericardial coelomic cysts [3]. First surgical resection for pericardial cyst was carried out by Lenox Hill in 1931 [4].
Case

A 32 year old woman presented with two months history of shortness of breath and recently changes of voice. No history of cough, appetite or weight loss. Routine blood investigations including liver and renal panels were normal. Chest x-ray and CT scan of thorax showed a large cyst mass occupying the anterior mediastinum abutting with the blood vessels (Figure 1A-1C). Pulmonary function test flow volume loop showed obstructive pattern extrinsic compression. Echocardiogram was normal.
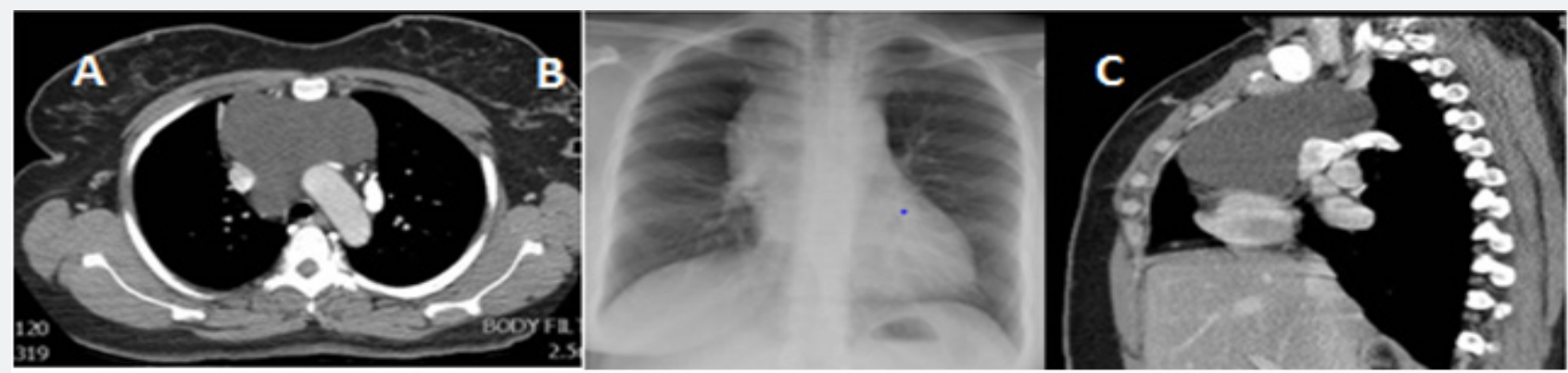

Figure 1: (A) Chest X-ray showing large mediastinal mass with smooth outline. (B) CT scan of chest revealed a large cystic lesion predominantly involving the anterior mediastinum insinuating between vascular structures. (C) CT scan thorax sagittal view showing anterior mediastinal mass 


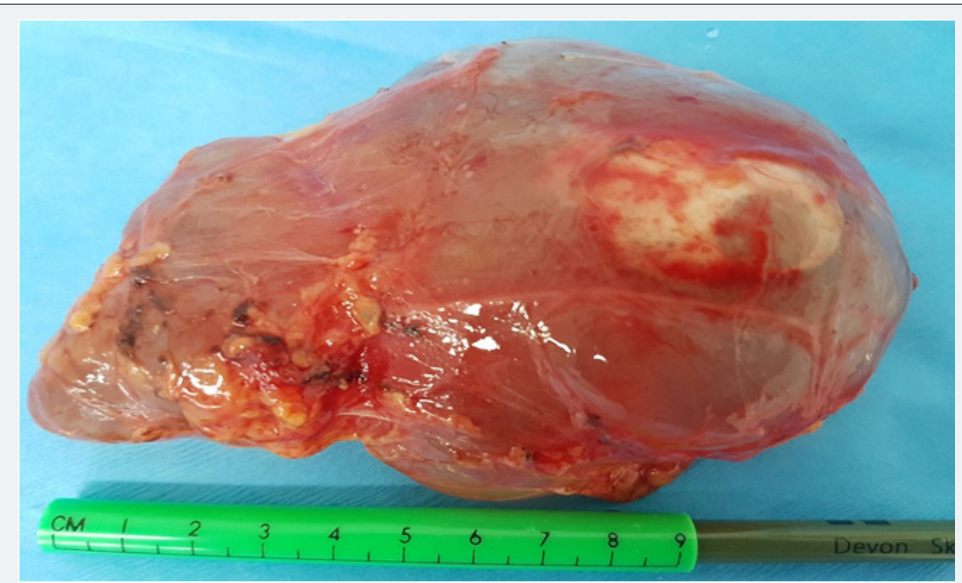

Figure 2: Macroscopic view of giant pericardial cyst about $15 \times 10 \mathrm{~cm}$, filled with a clear fluid.

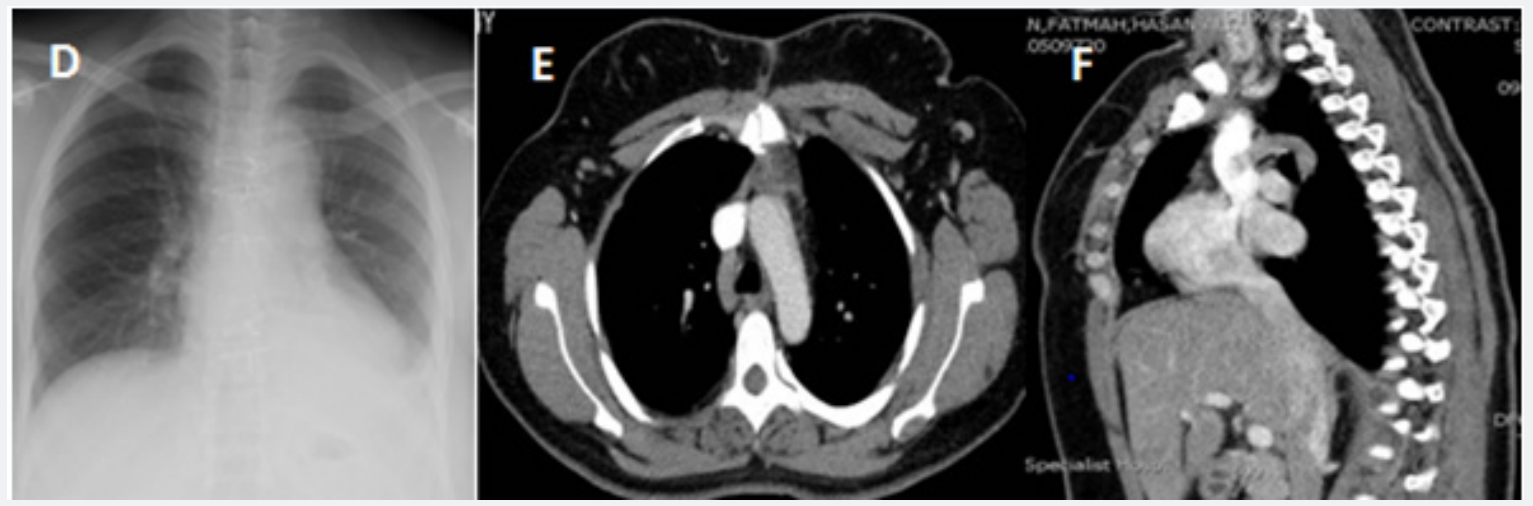

Figure 3: (D) Chest X-ray normal (E) Post-operative CT scan thorax (F) CT scan thorax sagittal view after the removal of cyst.

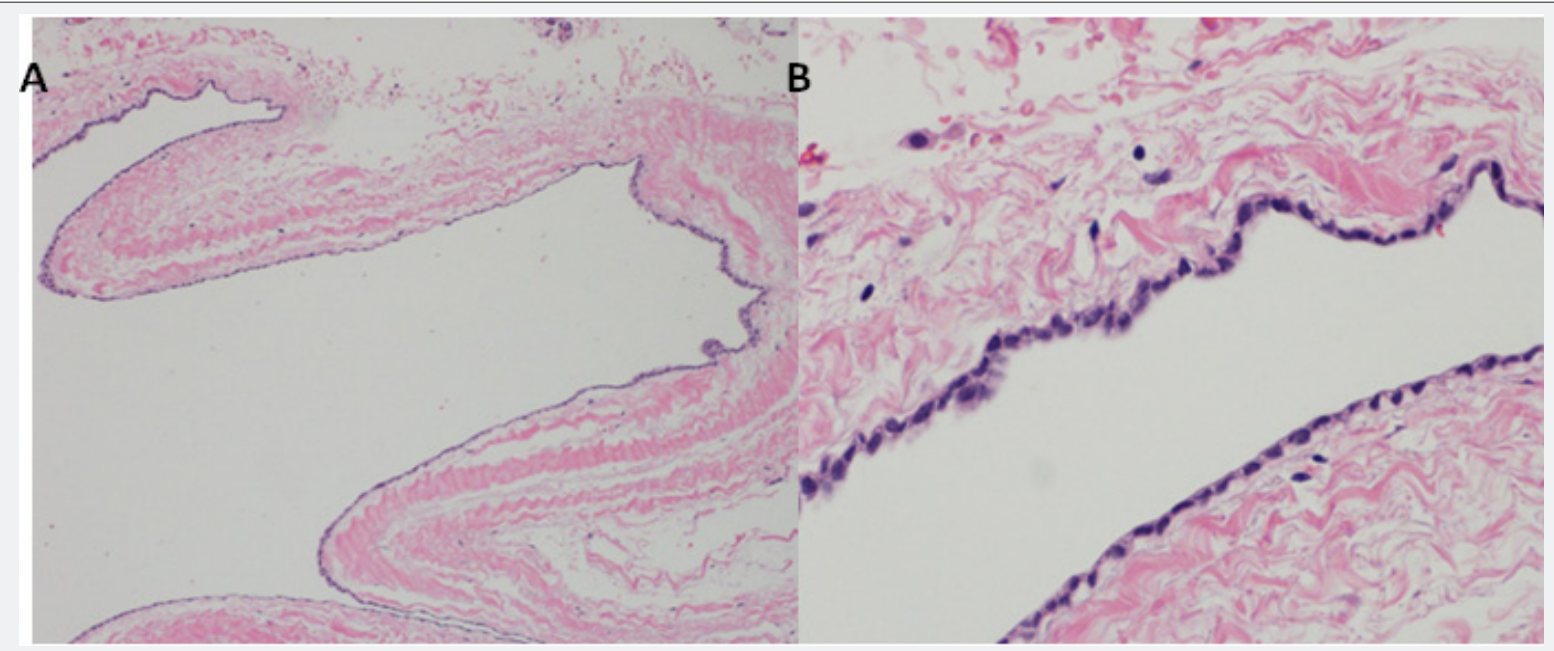

Figure 4: (A) Histopathology showed a cyst wall lined by a single layer of flattened or cuboidal cells. (B) Magnified view of the Cyst wall showing a single layer of mesothelial cells.

Surgical approach was median sternotomy and we found a giant cystic mass occupying the entire anterior mediastinum. The mass was resected in total with careful dissection as shown in Figure 2. Sternum was closed with wires. Patient was extubated on table and later on transferred to high dependency unit for overnight observations. Post-operative recovery was uneventful and she was discharged home. Five weeks later she check fibro optic bronchoscopy showed normal movements of vocal cards and her voice returned back to normal as well .Follow up chest $\mathrm{x}$-ray and CT of thorax showed mediastinal mass. (Figure 3D-3F) Histopathology report showed benign mesenchymal pericardial cyst (Figure 4A \& 4B). 


\section{Discussion}

Pericardial cysts are rare benign congenital lesions which occur due to failure of fusion of mesenchymal lacunae which form pericardial sac during embryogenesis $[5,6]$. Acquired pericardial cysts have been reported due to rheumatic pericarditis, tuberculosis. Hydatid disease, trauma and cardiac surgery [7]. They are commonly located at right or left cost phrenic angles $70 \%$ and $20 \%$ respectively, rest of $10 \%$ can be anywhere in the anterior or posterior mediastinum [8]. The best diagnostic imaging modality is CT scan or MRI scans of thorax although cardiac computed tomography and cardiac magnetic resonance imaging provides additional information about its relation with the heart. Normally these cysts contain clear fluid and diagnosis is easy but if the fluid protein content is high or infected then it's very difficult to differentiate them from other mediastinal malignant lesions $[9,10]$. Echocardiography is very useful tool to delineate the lesions located close to heart borders. Pericardial cysts are usually detected as incidental finding during chest imaging and majority of them are asymptomatic and are treated conservatively. Pericardial cysts can be detected prenatally after $14^{\text {th }}$ week of gestation and can regress spontaneously [11]. The symptomatic pericardial cysts are resected surgically as they can cause a lot of cardiac and non-cardiac complications due to their mass effect or by direct invasion of adjacent structures [12-16] (Table 1).

Table 1: Pericardial cyst-complications.

\begin{tabular}{|c|c|}
\hline Non -Cardiac & Cardiac \\
\hline Cyst Rapture & Cardiac tapenade \\
\hline Hemorrhage & $\begin{array}{c}\text { Right ventricular outflow tract } \\
\text { obstruction }\end{array}$ \\
\hline Cough & Pulmonary artery stenosis \\
\hline Shortness of breath & Congestive cardiac failure \\
\hline Hoarseness of voice & Arrhythmia \\
\hline Obstruction of main bronchus & Pericarditis \\
\hline $\begin{array}{c}\text { Lower respiratory tract } \\
\text { infection, }\end{array}$ & \begin{tabular}{c} 
Mitral valve prolapse \\
\hline Pneumonia
\end{tabular} \\
\hline Hemoptysis & $\begin{array}{c}\text { Sudden Cardiac arrest } \\
\text { Recurrent syncope }\end{array}$ \\
\hline Pneumothorax & $\begin{array}{c}\text { Erosion in to superior vena cava or } \\
\text { right ventricle }\end{array}$ \\
\hline
\end{tabular}

Feign et al. [17] reported thirty two patients out of 82 cases were symptomatic and they presented with chest pain, dyspnea, cough paroxysmal atrial tachycardia, pneumothorax, and hemoptysis. Unverferth et al. [18] reported series of twelve cases of pericardial cysts only two of them were symptomatic. Menconi et al. [19] reported three out of five cases with similar symptoms all of them were treated by surgical resection of cysts.

Management of pericardial cyst is three dimensional, conservative, aspiration and surgical resection Figure 5.

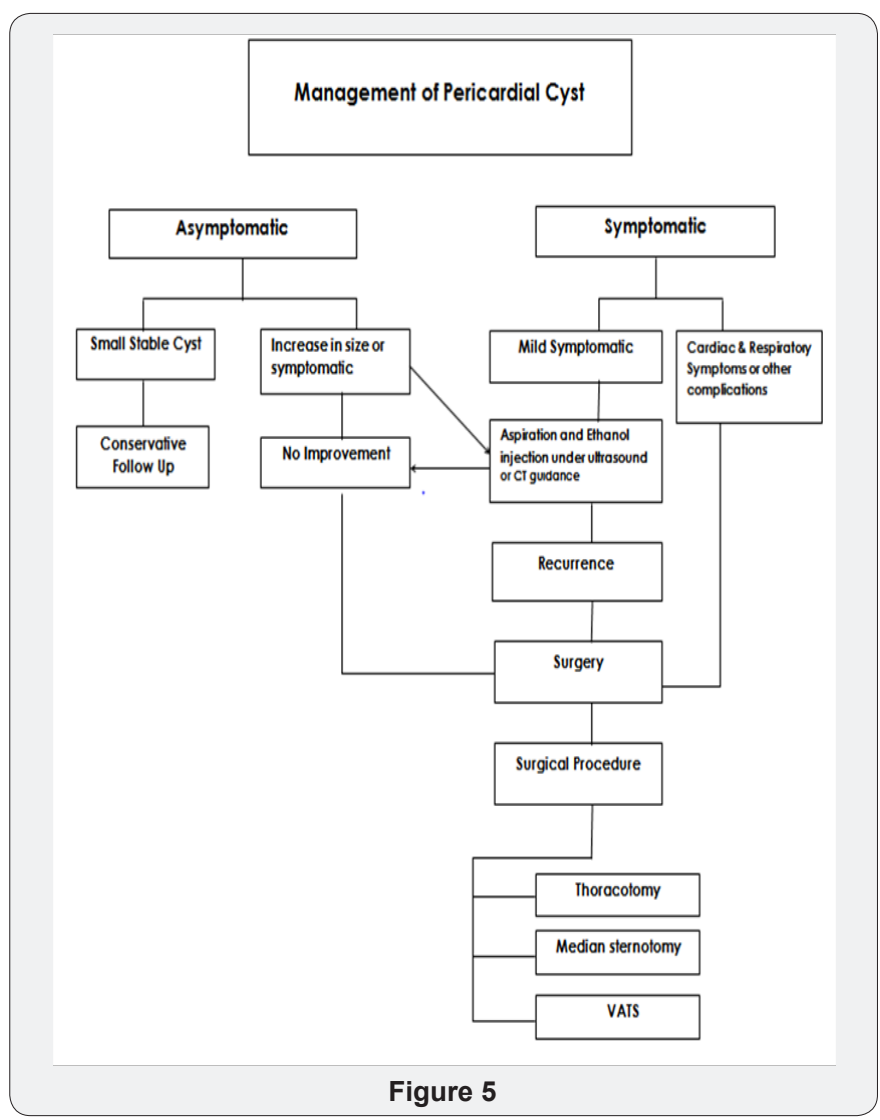

The European society of cardiology task force for management of pericardial diseases recommended percutaneous aspiration of pericardial cysts and ethanol sclerosis as first line of treatment [20].

\section{Conclusion}

We present a case of young women who presented with hoarseness of voice and shortness of breath due to giant pericardial cyst causing the compression of airway and left recurrent laryngeal nerve. Pericardial cyst was excised in total with excellent post-operative result. Patient dramatically improved after surgery and follow up bronchoscopy after five weeks showed normal movements of left vocal card and patient regained her normal voice.

\section{References}

1. Elamin WF, Hannan k (2008) Pericardial cyst: An unusual cause of pneumonia. cases J 1(1): 26.

2. Patel J, Park, Michael J, Rosen S, Kort S (2004) Pericadial cyst :case report and literature review. Echcardiography 21(3): 269-272.

3. Le Roux BT (1959) pericardial coelomic cyst. Thorax 14(1): 27-35.

4. De Rover p, Maisin J, Lacquet A (1963) Congenital pericardial cysts. Thorax 14: 27-35.

5. Lambert AV (1940) Etiology of thin-walled thoracic cysts. J Thorac Surg 10: 1-7.

6. Mazer ML (1946) True pericardial diverticulum; report of a case with safe operative removal. Am J Roentgenol Radium Ther 55: 27-29. 
7. Kosecik M, Karaoglanoglu M, Yamak B (2006) Pericardial hadatid cyst presenting with cardiac temponade. Can J Cardiol 22(2): 145-147.

8. Borges AC, Gellert K, Dietel M, Baumman G, Witts C (1997) Acute right side heart failure due to hemorrhage in to right pericardial cyst Ann Thorac Surg 63(3): 845-847.

9. Yared K, Baggish AL, Picard MH, Hoffman U, Hung J (2010) Multimodality imagining of pericardial diseases. JAAC Cardovasc Imaging 3(6): 650-660

10. Verhaert D, Gabriel RS, Johnson D, Lytle Bw, Daesi MY, et al. (2010) The role of multimodality imaging in the management of pericardial diseases. Circ Cardiovasc imaging 3(3): 333-343.

11. Lewis KM, Shere DM, Goncalves LF, Fromberg RA, Eglinton GS (1996) Mid-Trimester prenatal sonographic diagnoss of a pericardial cust Prenat Diagn 16(6): 549-553.

12. Mwita JC, Chipeta p, Mutagaywa R, Rugwizangoga B, Ussiri E (2012) Pericardial cyst with right ventricular compression. Pan Afr MedJ 12 60.

13. Kaul P, Javangula K, Farook SA (2008) Massive benign pericardial cyst presenting with simultaneous superior venacava and middle lobe syndrome. J Cardiothoracic Surg 3: 32.
14. Martins IM, Fernands JM, Gelapse CL, Brauullio R, Silva Vde C, et al. (2011) A large pericardial cyst presenting with compression of the right side cardiac chambers. Rev Bras Cir Cardiosasc 26(3): 504-507.

15. Lesniak Sobelag AM, Olszowska M, Tracz W (2008) Giant pericardial cyst compressing the right ventricle. Ann Thorac Surg 85(5): 1811.

16. Mohammad Q Najib, Hari P Chaliki, Amol Raizada, Jhansi L Ganji, Parsad M Panse, et al. (2011) Symptomatic pericardial cyst: a case series. Euro J Echog 12(11): E43.

17. Feigin Ds, Fenoglio jj, Mc Allister Ha, Madewell JE (1977) Percardial cysts: a radiologic-pathalogic correlation and review. Radiology 125(1): 15-20.

18. Unverth Dv, Wooley CF (1979) The differential diagnosis of paracardiac lesions: pericardial cysts. Cathet Cardiovasc Diagn 5(1): 31-40.

19. Menconi GF, Ambrogi MC, Mussi A, Melfi FM, Davini F, et al. (1998) diagnosis and treatment of pleuro-pericardial cysts role of vedio surgery. Milnerva Chir 53(7-8): 587-592.

20. Maish B, Sferovic PM, Ristic AD, Erbel R, RienmAller R, et al. (2004) Guidelines on the diagnosis and management of pericardial diseases executive summary; The task force on the diagnosis and management of pericardial diseases of the European society of cardiology. Eur Heart J 25(7): 587-610.

\section{Your next submission with Juniper Publishers} will reach you the below assets

- Quality Editorial service

- Swift Peer Review

- Reprints availability

- E-prints Service

- Manuscript Podcast for convenient understanding

- Global attainment for your research

- Manuscript accessibility in different formats

(Pdf, E-pub, Full Text, Audio)

- Unceasing customer service

Track the below URL for one-step submission https://juniperpublishers.com/online-submission.php 